\title{
Tapetosa, a new monotypic wolf spider genus from Western Australia (Araneae: Lycosidae: Lycosinae)
}

\author{
Volker W. Framenau ${ }^{1,2}$, Barbara York Main ${ }^{2}$, Mark S. Harvey ${ }^{1,2}{ }^{\text {and Julianne M. Waldock }}{ }^{1}$ \\ ${ }^{1}$ Department of Terrestrial Zoology, Western Australian Museum, Locked Bag 49, Welshpool DC, Western Australia \\ 6986, Australia. E-mail: volker.framenau@museum.wa.gov.au \\ ${ }^{2}$ School of Animal Biology, University of Western Australia, Crawley, Western Australia 6009, Australia
}

${ }^{3}$ Research Associate, Division of Invertebrate Zoology, American Museum of Natural History, New York, USA; Research Associate, California Academy of Sciences, San Francisco, California, USA

\begin{abstract}
A new monotypic Australian wolf spider genus, Tapetosa, with T. darwini as type species, is described for the 'Carpet Wolf Spider', which is known from granite outcrops in the southeastern Wheatbelt of Western Australia. Tapetosa belongs to the lycosid subfamily Lycosinae, but has a unique somatic morphology amongst wolf spiders, which is characterised by a dorso-ventrally flattened cephalothorax and abdomen associated with the spiders inhabiting narrow crevices under the granite sheets of rocky outcrops. The central tarsal claw is reduced and covered by extended scopulate setae probably facilitating movement on solid rocky surfaces. The tegulum of the male pedipalp carries a unique retrolateral protrusion.
\end{abstract}

\section{INTRODUCTION}

The first mention of an undescribed wolf spider exclusively inhabiting crevices under the rock slabs on granite outcrops in southwestern Western Australia was by Barbara York Main in her classic volume on Australian spiders (Main 1976). Her accompanying photograph (Main 1976; plate 25) showed a very unusual somatic morphology for a wolf spider; a dorso-ventrally flattened carapace and abdomen, and the third pair of legs oriented somewhat in a huntsman spider-like laterigrade fashion. In a subsequent publication, Main (2000) attributed the name 'Carpet Wolf Spider' to this species based on the carpet-like, mottled colour pattern (see Figure 1A). In the same publication, Main (2000) also provided some information on the biology of the species, describing it as a nocturnal forager that is territorial in regard to its home slab and foraging terrain. However, two immature spiders held in captivity were observed to come out of their rock crevice during the day to sit in the sun for short periods of time (JMW and Miriam Waldock, personal observation).

The Carpet Wolf Spider was initially placed in the genus Pardosa C.L. Koch, 1847 (Main 1976), although the author concluded later that the species 'may rightly belong taxonomically elsewhere' (Main 2000). This conclusion gained support when the subfamily Pardosinae Simon, 1898 was reported to be absent from Australia (Murphy et al. 2006; Yoo and Framenau 2006; Framenau 2007). However, the lack of adult specimens ensured that the Carpet Wolf Spider could not be assigned to any of the four subfamilies of Lycosidae known from Australia, Artoriinae Framenau, 2007; Zoicinae Lehtinen \& Hippa, 1979; Venoniinae Lehtinen \& Hippa, 1979, or Lycosinae Sundevall, 1833. Only recently, the male pedipalp morphology of the Carpet Wolf Spider could be examined when a penultimate male specimen, collected by Roberta Engel (University of Connecticut) and JMW during searches for Synsphyronus pseudoscorpions on rocky granite outcrops in July 2006, was raised to maturity in November 2006 by Miriam and Bill Waldock.

The Carpet Wolf Spider is not the only Australian lycosid that is found on rocky outcrops. Artoria impedita (Simon, 1909) appears to prefer rocky habitats and has been found mainly on or near granite outcrops (Framenau 2005). However, this species does not show the adaptations to living in narrow crevices such as a flattened body and reduced tarsal claws (see Description below). The non-aquatic fauna associated with granite outcrops in Western Australia was summarised by Withers and Edward (1997) and Main (2000), in which a small range of invertebrate and vertebrate animals were found to be restricted to granite outcrops. Others are not restricted to granite outcrops, but use them or their fringing aprons for part of their life cycle (Main 1997; Withers and Edward 1997).

The aim of this study is to describe the enigmatic Carpet Wolf Spider in a new genus of wolf spiders 


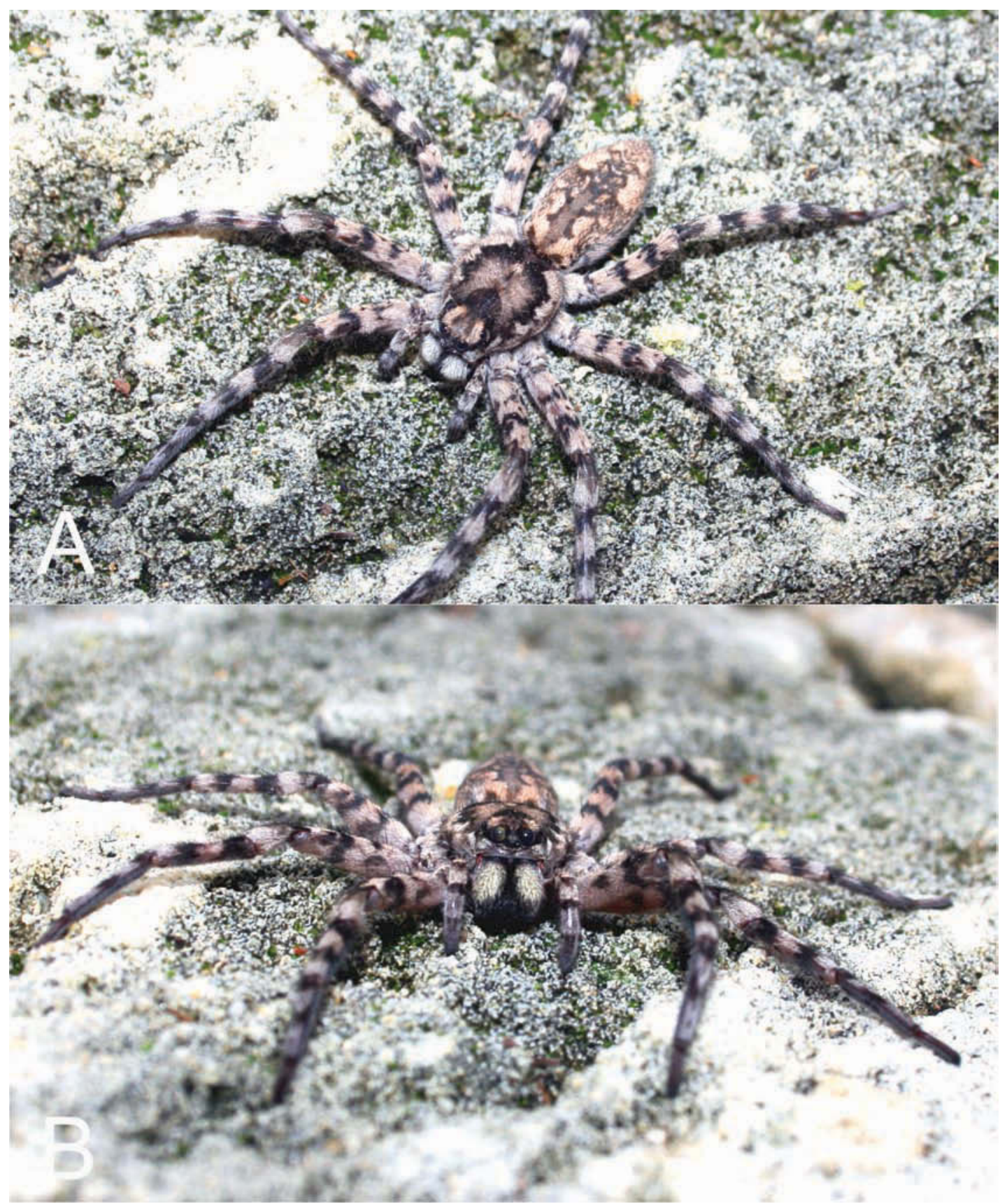

Figure 1 Tapetosa darwini sp. nov., immature from Lily McCarthy Rock (WAM T60365): A, dorsal and B, frontal view. (Photographs: V.W. Framenau)

to celebrate the $200^{\text {th }}$ anniversary of Charles Darwin's birth in 1809 and the $150^{\text {th }}$ anniversary of the publication of his On the Origin of Species by Means of Natural Selection (Darwin 1859).

\section{MATERIAL AND METHODS}

Descriptions are based on specimens preserved in $70 \%$ ethanol and lodged in the Western Australian Museum, Perth (WAM). For clarity, the setae have been omitted from the illustration of the male pedipalp. The morphological nomenclature follows Framenau and Baehr (2007) and Langlands and Framenau (in press). All measurements are in millimeters ( $\mathrm{mm}$ ).

Digital images of the male pedipalp were taken with a Leica DFC500 camera that was attached to a Leica MZ16A stereo microscope. Photographs were taken in different focal planes (ca. 20 images) and combined with the Leica Application Suite version 2.5.0R1.

The following abbreviations are used for eyes: anterior (AE), anterior median (AME), anterior lateral (ALE), posterior (PE), posterior median (PME), posterior lateral (PLE). 


\section{SYSTEMATICS}

\section{Family Lycosidae Sundevall, 1833}

Subfamily Lycosinae Sundevall, 1833

\section{Tapetosa gen. nov.}

\section{Type species}

Tapetosa darwini sp. nov.

\section{Diagnosis}

Carapace and abdomen dorso-ventrally flattened (Figures 1B, 2D); central tarsal claw reduced and covered by extended scopulate setae on all legs; leg I longer than leg IV [usually leg IV longest in Lycosidae, but see Artoria flavimana Simon, 1909 (Framenau 2002) and Allotrochosina schauinslandi (Simon, 1899) (Vink 2001)]; male pedipalp tegulum with retrolateral protrusion (Figures 2A,C).

\section{Description}

Large wolf spiders (total length estimated $18-30 \mathrm{~mm}$; male holotype is the only mature specimen known); males smaller than females; cephalothorax broad and dorso-ventrally flattened, as high in cephalic as in thoracic region (Figure 2D); row of AE narrower than row of PME; row of AE procurved; ALE comparatively small (Figure $2 \mathrm{E})$; clypeus narrower than diameter of AME; chelicerae with three promarginal teeth, with the central one largest, and three retromarginal teeth, with the apical smallest; labium longer than wide; abdomen dorso-ventrally flattened and elongated (Figures 1A,B); third pair of legs oriented somewhat laterigrade; leg formula I > IV > II > III; retrocoxal hymen present on femora; scopulae on all tarsi and metatarsi I and II; central tarsal claw comparatively small and concealed by extended scopulate setae. Tegular apophysis of male pedipalp forming a baso-ventrally directed broad hook (Figures 2A-C); tegular lobe large; terminal apophysis long and sinuous, tip of embolus pointing apicad; tegulum with retrolateral protrusion; cymbium tip with ca. 3-5 macrosetae. Female genitalia unknown.

\section{Etymology}

The generic name is composed of tapete, -is (Latin - carpet, rug) referring to the common name of this species, Carpet Wolf Spider, and -osa, a standard ending for wolf spider genera. The gender is feminine.

\section{Remarks}

The transverse tegular apophysis identifies Tapetosa as a member of the subfamily Lycosinae Simon, 1833 (Dondale 1986). The Australian representatives of this subfamily belong to two different lineages (Murphy et al. 2006). The first one, represented by Venatrix Roewer, 1960 and Tuberculosa Framenau and Yoo, 2006, appears to have invaded Australia from Asia whilst all other Australian Lycosinae are of Gondwanan origin with subsequent diversification in this country (e.g. Langlands and Framenau in press). Based on its morphology, i.e. the lack of a claw at the tip of the cymbium, and arid distribution, Tapetosa is believed to belong to the Gondwanan lineage of Australian Lycosinae. However, due to its extremely derived morphology it is currently not possible to hypothesize on the closest relatives of the genus. The flattened body shape is unique among wolf spiders.

Adult females of the Carpet Wolf Spider have so far not been collected and female genital morphology remains unknown. However, the distinctive somatic morphology in combination with the perceived threat to granite outcrops through human disturbances including activities of feral pigs which disturb exfoliated slabs (e.g. Main 2000) justifies establishing a new genus and species for this enigmatic wolf spider based on the knowledge a single mature male and juvenules alone.

\section{Distribution}

Tapetosa is exclusively found on granite outcrops in the southeastern parts of the Western Australian wheatbelt (Figure 3).

\section{Tapetosa darwini sp. nov.} Figures 1A-B, 2A-E, 3

Pardosa sp.: Main 1986: 111, plate 25.

\section{Material examined}

Holotype

Australia: Western Australia: ${ }^{1}$, McCann's Rock, $32^{\circ} 32^{\prime} 44^{\prime \prime} \mathrm{S}, 118^{\circ} 36^{\prime} 16^{\prime \prime} \mathrm{E}, 17$ July 2006 (collected as penultimate male, matured November 2006), under granite on outcrop, collected by J.M. Waldock and R. Engel (WAM T66693).

\section{Other material examined}

Australia: Western Australia: 1 penultimate

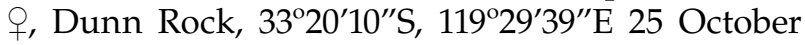
2000, site "Lake King 7", P. van Heurck, BYM 2000/ A3 (WAM T96970); 1 juvenile, Dunn Rock, 3320'S, $119^{\circ} 29^{\prime} \mathrm{E}, 1$ May 2000, foraging on rock, BYM2000/ A1, B.Y. Main (WAM T96971); 1 penultimate $\delta^{2}$, 1 penultimate + , 1 juvenile, Dunn Rock Nature

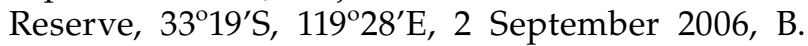
Muir (WAM T96803-5); 1 juvenile, 20 miles E of Lake King, near Rabbit Proof Fence on track to Narembeen Road, ca. $33^{\circ} 05^{\prime} \mathrm{S}, 120^{\circ} 01^{\prime} \mathrm{E}$, 23 May 1955, 


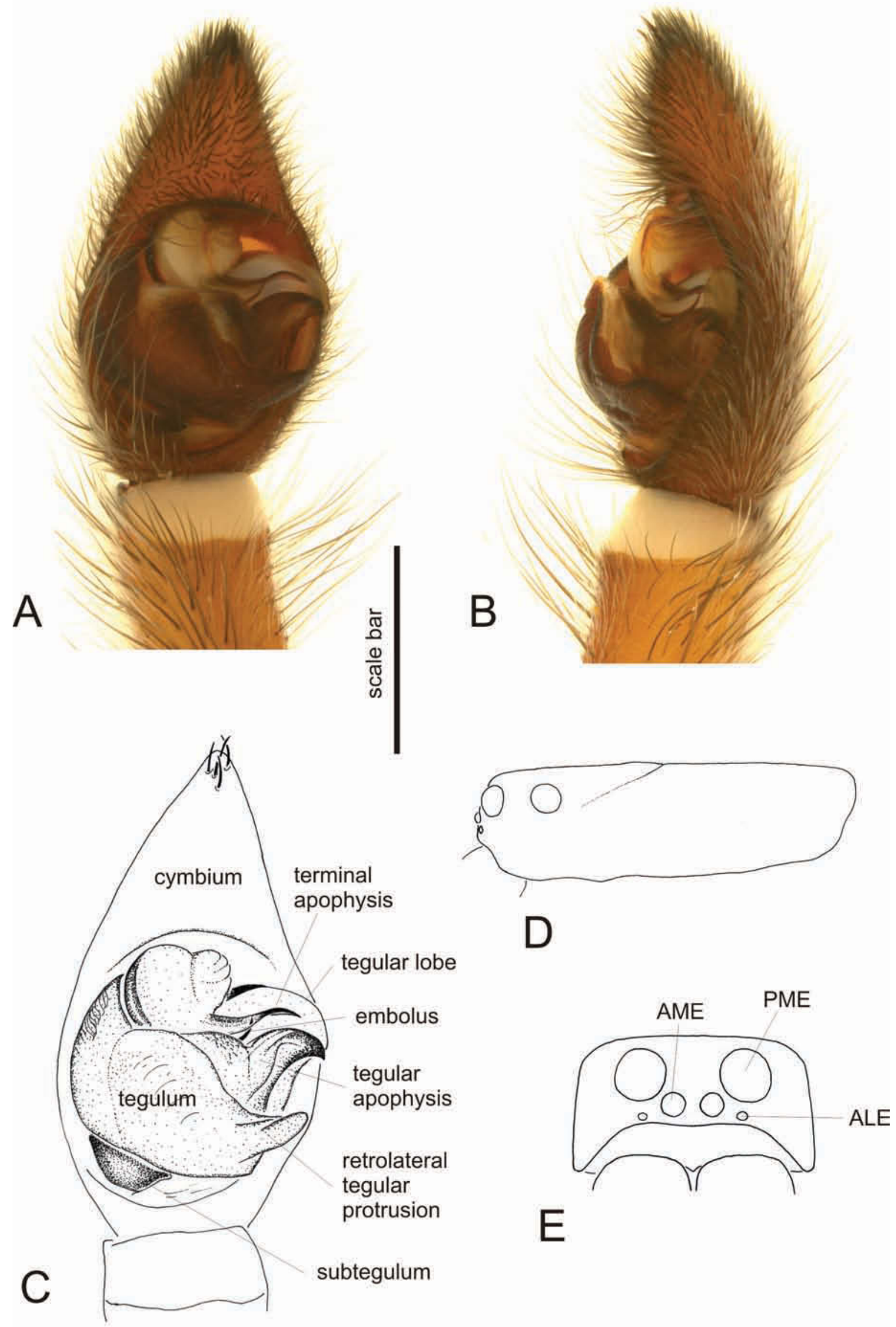

Figure 2 Tapetosa darwini sp. nov., male holotype (WAM T66693, from McCann's Rock, Western Australia): A, C, left pedipalp, ventral view; $B$, left pedipalp, retrolateral view; $D$, carapace, lateral view; $E$, eye pattern, frontal view. Scale bar: $\mathrm{A}, \mathrm{B}, \mathrm{C}=0.62 \mathrm{~mm} ; \mathrm{D}=5.62 \mathrm{~mm}, \mathrm{E}=3.48$. 
FN18, B.Y. Main, granite outcrop in sandplain heath (WAM T96972); 1 juvenile, same data, FN19 (WAM T96969); 1 penultimate male, Lily McCarthy Rock, $32^{\circ} 42^{\prime} 18^{\prime \prime} \mathrm{S}, 11^{\circ} 21^{\prime} 27^{\prime \prime} \mathrm{E}, 2$ March 2004, under granite slab, P. Mann (WAM T96968); 1 penultimate female, 2 juveniles, same data, except 2 May 2004 (WAM T60054, T60331, T60365); 1 penultimate male, Lily McCarthy Rock, $32^{\circ} 40^{\prime} \mathrm{S}, 119^{\circ} 20^{\prime} \mathrm{E}, 23$ October 2003, under granite slab, P.J. Mann (via A.F. Longbottom) (WAM T57584); 1 juvenile, same data (WAM T81169); 1 juvenile, Walyahmoning Rock, 30 38'S, $118^{\circ} 43^{\prime} \mathrm{E}, 1$ April 1972, head torch after dusk, granite surface or immediate surroundings, A. Baynes (WAM T9440 [formerly WAM 73/173]).

\section{Diagnosis}

As per genus.

\section{Description}

\section{Male (based on holotype)}

Carapace (compare juvenile Figures 1A,B): brown, centrally somewhat lighter; distinct light brown, wide and irregular submarginal bands; indistinct dark grey radial pattern; carapace densely covered with white and brown setae matching body colouration and few black macrosetae which are densest between the eyes and along carapace margin; dense white setae between PE.

Sternum: yellow brown with light grey pigmentation; covered with dense, adpressed grey setae; erect macrosetae along margin. Labium: brown; frontal rim white.

Chelicerae: dark reddish-brown; dense white setae mainly in basal half and few black bristles.
Pedipalp (Figures 2A-C): as per genus description.

Abdomen (compare juvenile Figure 1A): dark lanceolate cardiac mark in anterior half, dark transverse zigzag lines in posterior half, otherwise mottled with irregular dark and light patches; covered with white and brown setae matching body colouration and few black macrosetae; venter yellow-brown; covered with dense, adpressed grey setae. Spinnerets: brown.

Legs: light brown with distinct dark annulations; apical segments, in particular in leg I and II, darker. Spination of leg I: femur: 3 dorsal, 1 prolateral, 2 apicoprolateral, 3 retrolateral; patella: 1 retrolateral; tibia 3 ventral pairs, 2 prolateral; 1 retrolateral, 1 dorsal; metatarsus: 3 ventral pairs, 2 retrolateral.

Measurements. Male holotype. Total length 21.88, carapace length 10.25, carapace width 8.4. Eyes: AME 0.33, ALE 0.18, PME 1.09, PLE 0.94. Row of eyes: AE 1.94, PME 2.61, PLE 3.73. Sternum (length/ width) 5.25/3.50. Labium (length/width) 1.64/1.39. Abdomen length 11.50, abdomen width 6.88. Legs: lengths of segments (femur+patella+tibia+metat arsus + tarsus $=$ total length): Pedipalp 1.64 $+0.88+$ $1.07+-+1.39=4.98$, I $4.10+2.27+4.35+4.54+1.76=$ 17.01 , II $4.16+2.21+4.03+4.54+1.64=16.57$, III $3.78+1.95+3.15+3.91+1.64=14.43, \quad$ IV $4.41+2.02+3.78+4.85+1.89=16.95$.

\section{Female}

Mature females are not known, but penultimate females and juveniles agree in general somatic characters with the holotype male. Two penultimate females are larger than the holotype male suggesting sexual size dimorphism with larger females. The morphology of the female genitalia is unknown.

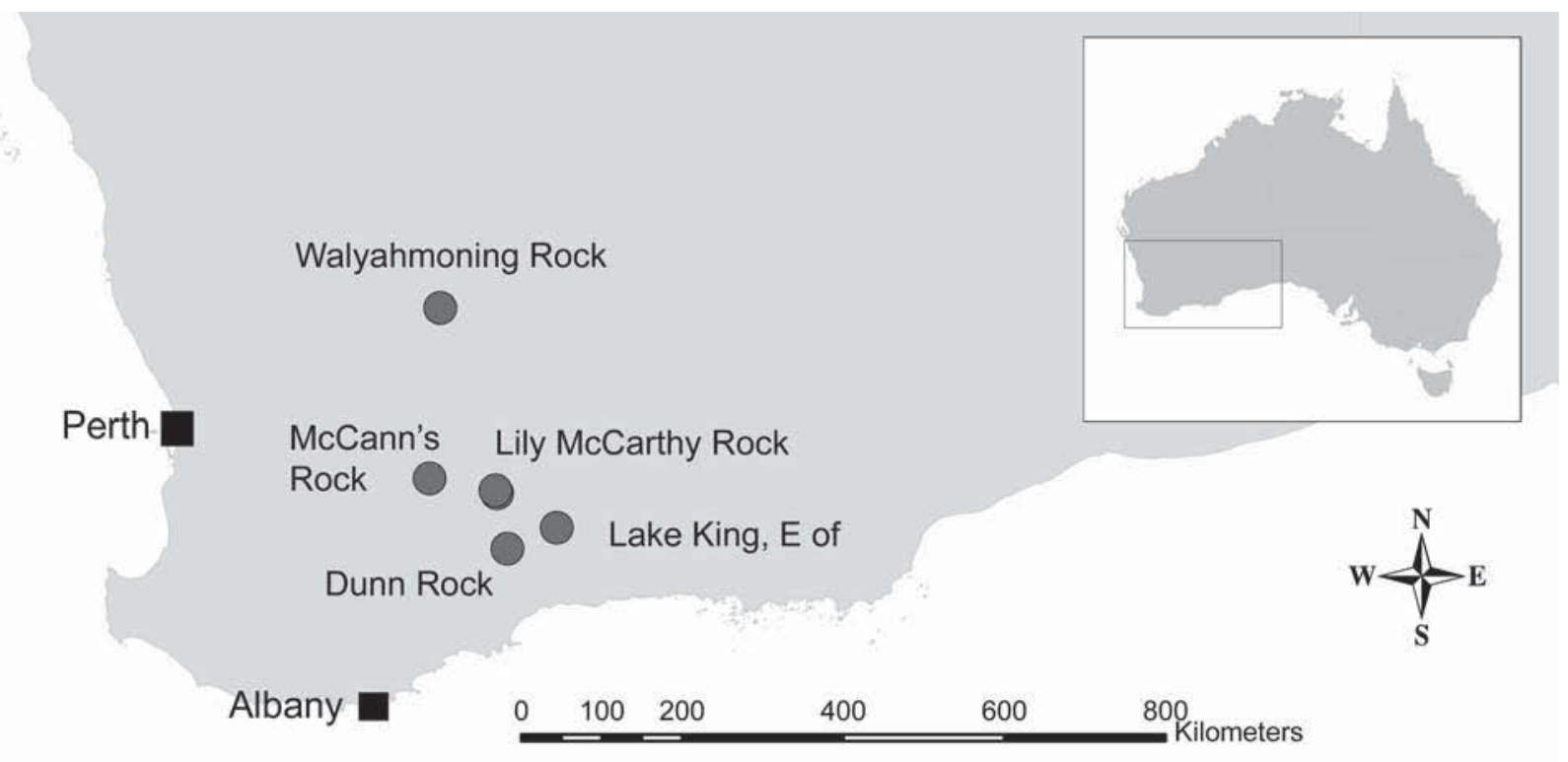

Figure 3 Distribution records of Tapetosa darwini sp. nov. in Western Australia. 


\section{Etymology}

The specific epithet is a patronym in honour of Charles Darwin (1809-1882).

\section{Life history and habitat preferences}

Tapetosa darwini is found exclusively on granite outcrops in Western Australia (Figure 3). It is not known with certainty whether the juveniles collected from Dunn Rock, near Lake King, Lily McCarthy Rock and Walyahmoning Rock are truly conspecific with the adult male from McCann's Rock.

The only known male matured in November, and penultimate males and females were found both before and after winter suggesting reproductive activity in early summer (November/December).

\section{ACKNOWLEDGEMENTS}

Miriam and Bill Waldock deserve special mention for patiently raising the male holotype to adulthood over a period of more than four months. This male is currently the only collected mature specimen of this species. We thank the reviewers Barbara Baehr (Queensland Museum, Brisbane) and Cor Vink (AgResearch, Christchurch) for valuable comments on the manuscript. VWF was funded by Rio Tinto and Aquila Resources when this paper was compiled. The initial phase of this study was funded by the Australian Biological Resources Study (ABRS) with a grant to Mark Harvey and Andy Austin (University of Adelaide) for a revision of the wolf spiders of Australia.

\section{REFERENCES}

Darwin, C. (1859). On the Origin of Species by Means of Natural Selection. London, Murray.

Dondale, C.D. (1986). The subfamilies of wolf spiders (Araneae: Lycosidae). Actas X Congreso Internacional de Aracnología, Jaca, España: 327-332.
Framenau, V.W. (2002). Review of the wolf spider genus Artoria Thorell (Araneae: Lycosidae). Invertebrate Systematics 16: 209-235.

Framenau, V.W. (2005). The wolf spider genus Artoria Thorell in Australia: new synonymies and generic transfers (Araneae, Lycosidae). Records of the Western Australian Museum 22: 265-292.

Framenau, V.W. (2007). Revision of the new Australian genus Artoriopsis in a new subfamily of wolf spiders, Artoriinae (Araneae: Lycosidae). Zootaxa 1391: 1-34.

Framenau, V.W. and Baehr, B.C. (2007). Revision of the Australian wolf spider genus Dingosa Roewer, 1955 (Araneae, Lycosidae, Lycosinae). Journal of Natural History 41: 1603-1629.

Langlands, P. and Framenau, V.W. (in press). Systematic revision of Hoggicosa Roewer, 1960, the Australian 'bicolor' group of wolf spiders (Araneae: Lycosidae). Zoological Journal of the Linnean Society.

Main, B.Y. (1976). Spiders. Sydney, London, Collins.

Main, B.Y. (1997). Granite outcrops: a collective ecosystem. Journal of the Royal Society of Western Australia 80: 113-122.

Main, B.Y. (2000). Habitat template for invertebrates on granite outcrops. Journal of the Royal Society of Western Australia 83: 139-147.

Murphy, N.P., Framenau, V.W., Donnellan, S.C., Harvey, M.S., Park, Y.-C. and Austin, A.D. (2006). Phylogenetic reconstruction of the wolf spiders (Araneae: Lycosidae) using sequences from the $12 \mathrm{~S}$ rRNA, 28S rRNA, and NADH1 genes: implications for classification, biogeography, and the evolution of web building behaviour. Molecular Phylogenetics and Evolution 38: 583-602.

Vink, C.J. (2001). A revision of the genus Allotrochosina Roewer (Lycosidae: Araneae). Invertebrate Taxonomy 15: 461-466.

Withers, P.C. and Edward, D.H. (1997). Terrestrial fauna of granite outcrops in Western Australia. Journal of the Royal Society of Western Australia 80: 159-166.

Yoo, J.-S. and Framenau, V.W. (2006). Systematics and biogeography of the sheet-web building wolf spider genus Venonia (Araneae: Lycosidae). Invertebrate Systematics 20: 675-712.

Manuscript received 24 April 2009; accepted 23 June 2009. 